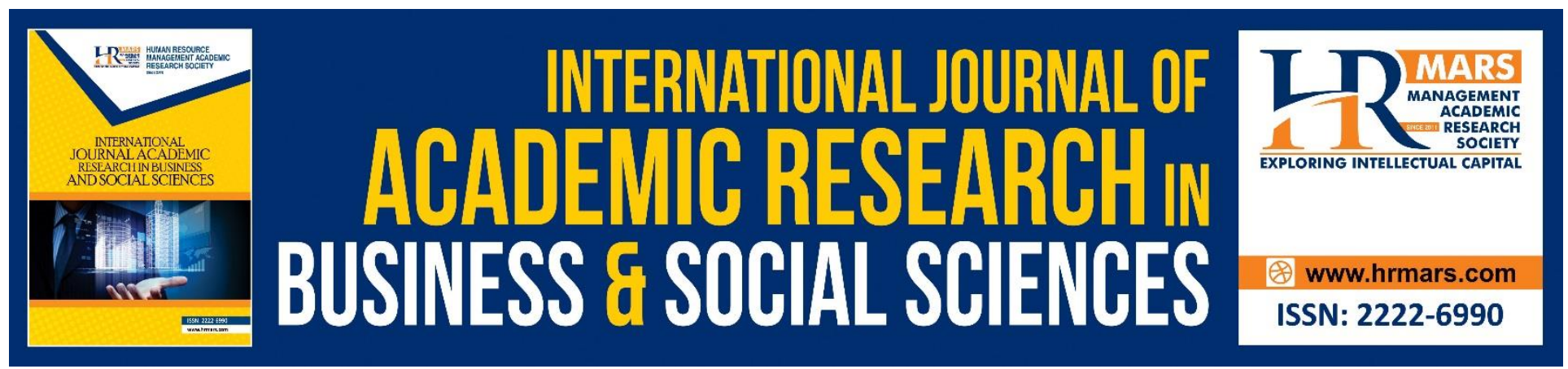

\title{
The New Approach of Understanding Hadiths Kawni Through Scientific Facts.
}

Helimy Aris, Syaril Nizam Omar, Nazri Muslim

To Link this Article: http://dx.doi.org/10.6007/IJARBSS/v10-i8/7527

DOI:10.6007/IJARBSS/v10-i8/7527

Received: 09 May 2020, Revised: 12 June 2020, Accepted: 19 July 2020

Published Online: 25 August 2020

In-Text Citation: (Aris et al., 2020)

To Cite this Article: Aris, H., Omar, S. N., \& Muslim, N. (2020). The New Approach of Understanding Hadiths Kawni Through Scientific Facts. International Journal of Academic Research in Business and Social Science, 10(8), 216-223.

\section{Copyright: (C) 2020 The Author(s)}

Published by Human Resource Management Academic Research Society (www.hrmars.com)

This article is published under the Creative Commons Attribution (CC BY 4.0) license. Anyone may reproduce, distribute, translate and create derivative works of this article (for both commercial and non-commercial purposes), subject to full attribution to the original publication and authors. The full terms of this license may be seen

at: http://creativecommons.org/licences/by/4.0/legalcode

\section{Vol. 10, No. 8, 2020, Pg. 216 - 223}

Full Terms \& Conditions of access and use can be found at http://hrmars.com/index.php/pages/detail/publication-ethics 


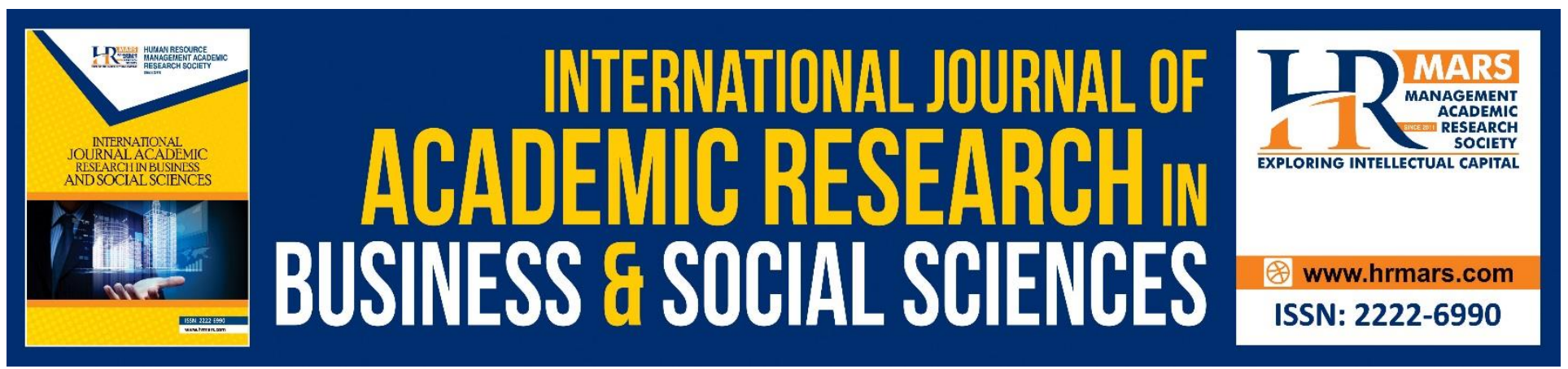

\title{
The New Approach of Understanding Hadiths Kawni Through Scientific Facts.
}

\author{
Helimy Aris, Syaril Nizam Omar, Nazri Muslim \\ Faculty of Quran \& Sunnah, Islamic Science University of Malaysia (USIM), Faculty of Science and \\ Technology, Islamic Science University of Malaysia (USIM), Pusat Citra Universiti, Universiti \\ Kebangsaan Malaysia (UKM) \\ Email: narim@ukm.edu.my
}

\begin{abstract}
Nabawi Hadith is the second source of Islamic Shari'a revealed by Allah s.w.t to MuHammad s.a.w. Other than explaining the laws, it also elaborates on matters related to the universe and humans (hadith kawni). Some of the hadiths include the group of mushkil al-hadith. In line with the exponential development of scientific fields, some of the scholars have benefited from scientific research in their understanding of the hadith texts. In most of the circumstances, scientific interpretations and i'jaz 'ilmi are seen to highlight the image of Islam as the religion of knowledge and science, sometimes causing some parties to make scientific interpretation blindly and carelessly. This study seeks to explain the guideline (dawabit) in understanding kawni hadiths through scientific research. The study outcome shows that scientific facts can be benefited as the wasilah in understanding kawni hadiths.
\end{abstract}

Keywords: New Approach, Kawni Hadith, Scientific Facts, Tafsir 'ilmi, I'jaz 'ilmi.

\section{Introduction}

Among the characteristics of nabawi hadiths is al-syumuliyah-it encompasses various topics and themes in life, in line with the holistic-oriented shari'a of Islam itself. Among the themes that have become the center of attention to these recent scholars is the science of human existence and the existence of the universe. The collection of kawni hadiths (related to the universe and humans) has started a long way, that was since the era when the sunnahs were compiled. Al-Bukhari, (2001) reserved a book in his al-Jami' entitled: "Kitab Bad al-Khalq (the start of the event) and it contains 17 chapters related to the universe. There are 160 hadiths including 22 mu'allaq, and 93 repeated hadiths. All were recorded by Muslim (1954) except for 15 hadiths. Al-Bukhari also recorded in the book 40 athar (statements) of the companions and tabi in (Ibn Hajar, 1959). Other than Bad al-Khalq, there were other titles similar to kawni hadith like al-Tibb (Medicine) and al-At imah (Food) where the titles can also be found in the works of other scholars like Muslim and al-Tirmidhi. Recent works lean more on scientific interpretations on kawni hadiths. Al-Najjar ( 2009) has listed nine scientific sub-themes and 79 examples of hadiths that carry science themes. SaliH Rida (Al-Rida, 2001) debated 
INTERNATIONAL JOURNAL OF ACADEMIC RESEARCH IN BUSINESS AND SOCIAL SCIENCES Vol. 10, No. 8, 2020, E-ISSN: 2222-6990 @ 2020 HRMARS

116 scientific sub-themes based on nabawi hadith. Yusuf al-Haj AHmad divided i'jaz 'ilmi into seven main themes and every theme is divided into more than five sub-themes.

The scientific discussions of hadith have been preceded by the interpretation of the al-Quran based on science, named al-Tafsir al-'Ilmi and scientific methodology in the (al-Manhaj al-'Ilmi fi al-Tafsir) that began as early as 5th Hijra. Some of the early advocators of this movement included al-Ghazali $(505 \mathrm{H})$, al-Baydawi $(685 \mathrm{H})$, al-Suyuti $(911 \mathrm{H})$. Earlier on, it was opposed by some of the scholars who did not agree with the scientific approach in the process of interpreting the al-Quran. Some of the earliest ones in protesting scientific interpretation would be Abu Hayyan al-Andalusi (745H) and alShatibi (790H) (Al-Dhahabi, 1978).

Although the term al-SharH is commonly used for the process of elaborating hadiths, the terms alTafsir al-'Ilmi has begun to be used by some of the scholars in elaborating upon the science-themed hadiths. The works of Yusuf Ismail (2015) and SaliH al-Amin al-Ma'iz (2018) employ the term al-Tafsir al-'Ilmi to explain the benefits of dates in the hadith.

Following the al-Tafsir al-'llmi movement, another movement emerged in harmonising the revelation and scientific facts or al-I'jaz al-'Ilmi. Al-I'Jaz al-'llmi not al-Tafsir al-'Ilmi. Yet, both are inter-related and both use scientific approach.

\section{The Definition of Tafsir IImi, I'jaz 'Ilmi and the Association between both}

There are various definitions for 'ilmi. Al-Juday' (2001) explaining tafsir 'ilmi as the elaboration on verses with the themes of the universe, human existence and so on using scientific facts that have yet to be known previously. The definition limits the ilmi to certain verses only and not the entire verses of the al-Quran. According to al-Zandani (n.d.), Tafsir 'llmi is the elaboration on the meaning of the Quranic verses or nabawi hadiths based on the scientific theories. Al-Zandani's definition also includes two other elements which is the elaboration of nabawi hadiths and interpretation based on scientific theories. According to al-Rumi (2003), tafsir 'ilmi exposes the relationship between Quranic texts and scientific facts. This is the humans' attempt to delve into the meanings of the Quran (Al'Alamiyah, n.d.).

I'jaz 'Ilmi is the revelation through al-Quran or Sunnah about a scientific fact where it is beyond the understanding yang mana ia adalah di luar kemampuan minda dan pencapaian manusia pada zaman Rasulullah s.a.w (Al-Zandani, n.d.).

Clearly, I'jaz 'Ilmi is not a form of interpretation but a statement about the reality that has proven scientifically. Nonetheless, the statement requires an interpretive methodology that can expose the reality intended. The methodology is tafsir 'ilmi. Thus, it can be concluded that tafsir 'ilmi is the wasilah to i'jaz 'ilmi. As the objective of i'jaz 'ilmi is normally found on verses that concern with the universe and humans, tafsir ilmi only focuses on the following verse also known as al-ayat alkawniyah. Due to the fact that hadiths containing the same themes and their relations to scientific facts can lead to proof of the truth brought by Muhammad s.a.w and Islam, some of the scholars also included the studies of kawniyah hadiths in the scope of interpretation of 'ilmi dan ijaz 'ilmi. 
INTERNATIONAL JOURNAL OF ACADEMIC RESEARCH IN BUSINESS AND SOCIAL SCIENCES Vol. 10, No. 8, 2020, E-ISSN: 2222-6990 @ 2020 HRMARS

\section{The Implication of tafsir 'ilmi}

Scientific methodology is believed to be able to strengthen the understanding towards Quranic and hadith texts especially those with the theme of the universe and humans. It is not only testament to the supremacy of Allah s.w.t as the Divine power of the universe, but it also drives us to believe in the truth of the al-Quran and hadith (Al-Qudah, 2008). In the knowledge of hadith, scientific methodology is seen to be able to remove the ambiguity in understanding some of the mushkilat alahadith (hadiths seen as contradictory to the evidence of shar' $i$ and the mind). Some of the rejected hadiths as the matan contains information thought to be impossible, contradict the al-Quran and with the source of israi iliyaat the status gets to be reconsidered when science proves that it does exist and it is not impossible (Al-Qudah, 2008). Even so, scientific discovery also helps in understanding the actual process of human existence stated in several hadiths and at the same time, the laws of figh built upon certain understanding that can be reevaluated so that it will be consistent with the progress of the science and technology (Al-Qudah, 1986).

Other than that, understanding and interpretation based on scientific methodology should be able to expose Islamic revelations as a discourse that is relevant in all eras, advocating the spread of knowledge, and in tandem with modern scientific laws. This should be able to rectify the misconception held by some parties on the religion and the belief that religion and knowledge or science are two separate aspects.

Nevertheless, the process is also seen to cause Quranic texts and Hadiths to be manipulated according to a certain theory- the interpretation also strays from the actual meaning, since there is no clear guideline. For instance, the verses in the al-Quran and Hadith have outperformed science in some discoveries due to the fact that there have been several signals fromb oth with regard to the said discoveries, and this is not within the actual meaning conveyed in the al-Quran and hadith (Hilmi, 1982). Apart from that, finding facts or theories through the Quran and Hadiths would lead to the misunderstanding on the main role of both revelations as the source of faith. Havign science as the basis of interpretation to the verse or hadith can cause takalluf or over-explanation that can lead to deviancy in the religion. Connecting the texts of the Quran and hadiths with ever-changing traits, can make both revelations exposed to criticisms and arguments (Al-Rumi, 2003). Placing something without any form basis at all, onto Muhammad s.a.w in the name of i jaz 'ilmi is also included as counterfeiting hadith.

However, some of the scholars opined that a hadith with the status of da'if can be classified as Hasan if it is consistent with scientific facts (Al-Qudah, 2008). Some of the scholars have the opinion that scientific facts or logic cannot be considered as supporting the hadith da if so it is evaluated as Hasan or thought of as part of Prophet's hadiths (Bazamul, 2003).

\section{Guideline}

According to the writer, scientific methodology in understanding revelation texts and the association between scientific facts and the reality found in the al-Quran and hadith can give an additional meaning to mukjizat under the condition that it considers the following aspects: 
INTERNATIONAL JOURNAL OF ACADEMIC RESEARCH IN BUSINESS AND SOCIAL SCIENCES Vol. 10, No. 8, 2020, E-ISSN: 2222-6990 @ 2020 HRMARS

\section{The Existence of a Hadith before it Becomes an Argument}

The status of a hadith must be ascertained first before it becomes the basis of practice. All Muslim scholars are in unison to accept verified hadiths and hasan as the basis of the laws. There has been a dispute in accepting hadith da if as evidence. However, none of the hadith experts or fiqh members have legitimised hadiths that are too da'if and mawdu'. The importance of checking for the validity of the hadiths is seen through the statement made by Ibn Sirin $(110 \mathrm{H})$ as reported by al-Imam Muslim (261 H) in al-SaHiH (Hajjaj, 1954)

"They (hadith experts) have never asked about sanad. As a slander takes place (after the murder of Uthman ibn 'Affan in $35 \mathrm{H}$ ) they began to ask, name us your rijal. So if the one reporting it was a member of the sunnah, the hadith would be used. If the one reporting was a member of the bidaah, the hadith would be rejected"

When a hadith has been verified based on the methodology, scietific elaborations might be able to be of use when it comes to understanding the meaning of the hadith. Any empirical fact or scientific law can be fundamental to the actual meaning of a hadith. According to al-Zandani ( n.d.), if a piece of evidence or nas is zanni, it has to be explained in line with scientific facts. If a scientific fact contradicts a hadith that is naturally zanni al-thubut, the hadith has to be explained so that it will be consistent with the contradicting fact. If the meaning cannot be made consistent together with scientific facts, the facts must be prioritised compared to the hadith that is characteristically zanni.

For example, based on evidence (the clearest meaning in mind) of the Ibn Mas'ud r.a hadith, the proper process of the embryo formation takes 120 days. However, the fact shows that it happens in 40 days. Here, the hadith has to be explained in line with the facts. Additionally, several other hadiths that are also verified contain meanings consistent with the embryology facts (Al-Qudah, 2008).

If a status of a hadith is considered da'if, (caused by the issues on the sanad), da 'if jiddan or mawdu', there is no need to examine the meaning or to use scientific facts to support the meaning. In this situation, it is unreasonable to label the meaning of a hadith that is proven da'if as i'jaz 'ilmi merely because it is consistent with scientific discovery. Hadith da if means most probably it does not exist or it is not the statement made by the Prophet. The need to believe in hadith da if and the validity of the hadith based on the methodology of the fiqh members cannot serve as the basis to the justification of using scientific facts to support hadith da if and to continue to see it as i'jaz 'ilmi. This is because the need to succumb to hadith da' if is confined by the term and condition stipulated. One of them is not it is not based on Prophet s.a.w (Al-Asqalani, n.d.). scholars have the tendency to evaluate this verified hadith although there is an issue with the sanad as it is consistent with the text of the Quran, ijma' and the generality of Syara'. However, the validity of the matan based on the fiqh members' consideration does not mean that the sanad is also valid and we can rest them on the Prophet. In this issue, what is meant as Hujjah would be the Quranic texts, ijma' and the common laws of syara' and not the hadith da'if. Thus, scientific facts or logic cannot be weighed upon as supporting a hadith da'if so they are evaluated as Hasan or thought to be part of the hadiths of the Prophet s.a.w (Bazamul, 2003). 
INTERNATIONAL JOURNAL OF ACADEMIC RESEARCH IN BUSINESS AND SOCIAL SCIENCES Vol. 10, No. 8, 2020, E-ISSN: 2222-6990 @ 2020 HRMARS

\section{Understanding Hadith Texts}

It is important to understand the hadiths based on the language and the time in which the hadiths came. The Arabic words often used for nabawi hadithsnormally contain more than one meaning. Thus, the meaning of Haqiqi (main or surface meaning) and majazi (second meaning) must be distingushed. The istinbat usuli method is really helpful in understanding these Arabic texts. As the meanings supporting a fact or scientific law are obtained through various indicators, like dalalat almantuq al-sariH (actual meaning of an utterance), dalalat al-isharah (meaning beyond the intended meaning and whether the statement is correct or not is not dependent on it), dalalat al-ima (statements containing the premise or the basis of a law), and dalalat al-mafhum (not the meaning of a statement but understood from it), the knowledge of dalalat al-lafz (Al-Najjar, 2009) must be mastered.

There are also words with meanings changing through time, such as al-taswir, al-sa iH. Thus, it is important to know the time frame of a term. There are also words that are seldom used (gharib). The knowledge about the references related to al-alfaz al-gharibah (rare utterances) is truly helpful in these matters.

Other than that, several other aspects have to be considered in understanding the hadith like the context, topic, sabab al-wurud (the original story) and maqasid al-shari'ah. Some of them are only known through sabr al-riwayat wa al- alfaz (collecting the stories and narrations of the hadith). As long as it does not contradict the Arabic methods, it is allowed although it is out of the context. For instance, in the hadith Hudhayfah bin Usayd r.a (Hajjaj, 1954, no:2645) the process of human existence is explained from the embryo although the actual context explains about fate. That said, explaining without linguistic reason (takalluf) merely to support a fact or theory is prohibited at all costs (Al-Najjar, 2009).

Possibly, some of the utterances or narrations are seen to contradict other sources of utterances or narrations. Thus, one should understand the methods adopted in dealing with mukhtalif al-hadith or mushkil al-hadith. Some of the things stated in the hadith are the wasilah that keeps changing through time and situation. The main issues are mantained and need to be understood. For example, the use of the sugi or chewing stick is a consistently changing wasilah. The main aim for its use is for dental and mouth care (Al-Qaradawi, 1992; Al-ZuHayli, 2006).

\section{Tafsir 'ilmi is not the only way to Understand Hadith}

As MuHammad s.a.w was granted jawami' al-kalim (a brief expression but very meanignful) and Arabic words are considered Hammalat awjuh (having more than one meaning), tafsir ilmi is not the only way to understand hadith nabawi. In other words, the demand for understanding the laws from hadiths is not just met with tafsir 'ilmi. Studies in this field (i jaz 'ilmi) show that most of the meanings consistent with the facts are obtained through dalalat al-isharah (beyond the meaning intended by the speaker and whether it is true or not does not depend on it) and all the laws and teachings needed are issued and debated by previous Muslim scholars. Tafsir 'ilmi functions to consolidate the existing understanding. Thus, it is not reasonable to make light the efforts and contributions of the previous scholars who had worked really hard in delving into the true meanings of the hadiths and extracting the laws from them (Al-Najjar, 2009). 


\section{Verification of Facts}

A fact that is connected to a hadith must be verified beforehand by experts. If the facts are the already existing discovery, the reference of the facts must be academic in nature (Al-Najjar, 2009). As science is based on observations and experiments (Encyclopaedia, n.d.) and the decisions are forever changing, it is reasonable to confirm the value of a finding that is to be related to the meaning of a hadith. Theoretical scientific laws cannot be chosen as the method in interpreting hadith texts. This can make the revelations disputable when the supporting theories are rejected and even questioned.

\section{Avoid the Detailed Argument on I'jaz 'ilmi}

The purpose of the scientific methodology is to understand the hadith kawni which mostly lean on scientific interpretation delivered by MuHammad s.a.w. The need to understand hadith kawni stems from the actual function of the revelations as the source of faith. Detailed and intricate studies on a given topic involving certain specification and expertise need to be avoided (Al-Najjar, 2009). This causes the understanding of hadith to not leading to the original reason as to why the scientific methodology is developed in the Quranic and hadiths interpretation. Assuming that the al-Quran as well as hadith - as the reference for Physics, Chemistry or any branch of knowledge would serve as the misconception about the actual trait and role of these revelations (Al-Rumi, 2003).

\section{Conclusion}

Based on past discussions, scientific facts can be used in the understanding of nabawi hadithseven more so for the hadiths that contradict any evidence of shar' $i$ and the mind. However, it has to take into account the validity of the hadith, the understanding of the meaning based on Arabic framework and the method of istinbat usuli, the identification and confirmation of facts from experts. Detailed debates more interconnected with science compared to hadiths mut be avoided. Tafsir 'ilmi is not the only way to understand revelations. Even in most cases, it is more on the consolidation of meaning and the laws decreed by previous scholars of hadiths.

These things need to be taken into account as a new guide and model in understanding the hadith kawni, especially those categorized as mushkil al-hadith. It has the potential to highlight the side of knowledge that exists in the sunnah of the Prophet Muhammad s.a.w in facing the era of science and technology by maintaining the authenticity of Islamic sources through a correct understanding and guided by authentic methods.

\section{References}

Al-Asqalani, I. H. (n.d.). Tabyin al-'Ajab bima warada fi Shahr Rajab. Egypt: Muassasat Qurtubah.

Al-Bukhari, M. (2001). SaHiH al-Bukhari. No city: Dar Tawq al-Najah.

Al-Dhahabi, M. (1978). Al-Tafsir wa al-Mufassirun. Cairo: Maktabat al-Wahbah.

Al-Juday', A. A. (2001). Al-Muqaddimat al-Asasiyah fi 'Ulum al-Qura`an. United Kingdom: Markaz alBuHuth al-Islamiyah.

Al-Ma'izi, SaliH. (2018). Al-Tafsir al-'Ilmi li al-AHadith al-Nabawiyat al-Sharifah. Majallat Al-Jami'ah Li Al-Dirasat Al-Islamiyah, 26(2), 371-398.

Al-Najjar, Z. (2009). Madkhal Ila Dirasat al-l'jaz al-'Ilmi fi al-Qur’an al-Karim wa al-Sunnat alNabawiyat al-Mutahharah. Beirut: Dar al-Ma'rifah.

Al-Qaradawi, Y. (1992). Kayf Nata'amalu Ma'a al-Sunnat al-Nabawiyah. USA: Al-Ma'had al-'Ali li al- 
INTERNATIONAL JOURNAL OF ACADEMIC RESEARCH IN BUSINESS AND SOCIAL SCIENCES

Vol. 10, No. 8, 2020, E-ISSN: 2222-6990 @ 2020 HRMARS

Fikr al-Islami (IIIT).

Al-Qudah, S. (1986). Mata tunfakhu al-RuH fi al-Janin. Majallat Dirasat Al-Jami'at Al-Urduniyah, 13(12).

Al-Qudah, S. (2008). 'Alaqat al-Nas al-Shar'i bi al-'Ulum al-Tabi iyah. Al-Jami'at al-Urduniyah. Al-Rida, SaliH. (2001). Al-l'jaz al-'Ilmi fi al-Sunnat al-nabawiyah. Riyad: Maktabat al-'Ubaykan. Al-Rumi, F. (2003). Dirasat fi 'Ulum al-Qur’an.

Al-Zandani, A. al-M. (n.d.). Ta`sil al-l'jaz al-'Ilmi fi al-Qur’an wa al-Sunnah. Beirut: Al-Maktabat al'Asriyah.

Al-ZuHayli, M. (2006). Al-Wajiz fi Usul al-Fiqh al-Islami. Syria: Dar al-Khayr.

Al-'Alamiyah, M. J. al-M. (n.d.). Al-I'jaz al-'Ilmi fi al-Qur’an al-Karim. Jami'at al-Madinat al-'Alamiyah.

Bazamul, M. (2003). Taqwiyat al-Hadith al-Da'if Bayn al-Fuqaha' wa al-MuHaddithin. Majallat

Jami'at Umm Al-Qura Li 'Ulum Al-Shari'ah Wa Al-Lughat Al-'Arabiyah Wa Adabiha, 15(26).

Encyclopaedia, B. (n.d.). science | Definition, Disciplines, \& Facts.

Hajjaj, M. Bin. (1954). SaHiH Muslim. Beirut: Dar IHya`al-Turath al-'Arabi.

Hilmi, A. Hafiz. (1982). Al-'Ulum al-Biyulujiah fi Khidmat Tafsir al-Qur’an al-Karim. Alam Al-Fikr, 12(4).

Ibn Hajar, A. bin 'Ali. (1959). FatH al-Bari. Beirut: Dar al-Ma'rifah.

Ismail, Y. (2015). Al-Tafsir al-'Ilmi li AHadith al-Tamr. Majallat Ma'alim Al-Qur'an Wa Al-Sunnah. 